\title{
Regional Product Mapping Analysis of East Java's Leading Product 2010-2014
}

\author{
Grisvia Agustin \\ Economics Faculty, Universitas Negeri Malang
}

\begin{abstract}
Rapid growth of East Java Province supported by intensive interregional and international trade. Intensity of East Java Province interregional and international trade can be measured by Regional Product Mapping Model to identify leading products from variuos sectors. So researchers want to identify leading product mapping by $S L Q$ and TBI indicators and analyse it using statistic descriptive to forecast specialization tendency in the future by analyse mean, median, modus and skewness of SLQ and TBI indicators.Leading export products of East Java and Indonesia is in Grup A (first quadrant). While at Grup B (second quadrant) there are export products which only lead in regional/province scale, but not in national scale because East Java export proportion of the products is relatively small when it compared to export value of the same product type which yield in all provinces nationally. At Grup C (Third Quadrant) there are 6 export product types with positive TBI value positive and negative $S L Q$ value. Low $S L Q$ indicates that export strength of East Java export products still low compared to export strength of the same export product type which is produced from entire provinces in Indonesia. Fourth quadrant is group products with negative value of TBI and SLQ. It means that these products represent product whit higher export value than its import. Strength of export products is weak in East Java and Indonesia.Average value of TBI and $S L Q$ show improvement of export strength because it indicates that the increasing of $S L Q$ average value represents reinforcement of East Java product advantage along time and improvement of TBI average value shows bigger proportion of East Java export product along time. Positive value of $S L Q$ skewness in certain year indicates that the state more concentrate at product with low comparative advantage. While negative value of TBI skewness indicate that East Java more focus at nett export product. Producers in East Java have strong export potention although they must improve its exporting product advantage.
\end{abstract}

Keywords: regional product mapping, symmetric location quotient, trade balance index, descriptive statistics.

\section{Introduction}

Economic growth of East Java Province in 2014 is 5.86 percent. East Java Province shows higher growth than average growth of any other provinces in Indonesia. Real Growth Domestic Regional Bruto of East Java at 2014 is Rp. 1.540,7 trillion and real GDP percapita is Rp. 39,9 million or equal to USD 3.362,1. Economy of East Java at 2014 is growing 5,86 percent. Growth happens in entire fields. Economy structure of East Java at 2014 is dominated by two special sectors that are

- Manufacture Industry (28,90 percent);

- Agriculture, Forestry and Fishery (13,73 percent)

(Statistical Center Instituition, 2015)

Rapid growth of East Java Province supported by intensive interregional and international trade. Intensity of East Java Province interregional and international trade can be measured by Regional Product Mapping Model to identify leading products from various sectors. Regional Product Mapping Model is developed by research development team of Economics Faculty in Universitas Negeri Malang using Symmetric Location Quotient (SLQ) and Trade Balance Index. SLQ is symmetric form of Location Quotient (LQ) indicator which able to determine base sector/pre-eminent sector. SLQ iindicator is trying to measure concentration from sector activities by calculating contribution of economy sector in certain region and compare it with the same economy sector in broader region symmetrically (McCann, 2001). TBI concept is employed to analyse region specialty in trade activities. So researchers want to identify leading product mapping and analyse it using statistic descriptive to forecast specialization tendency in the future by analyse mean, median, modus and skewness of SLQ and TBI indicators.

\subsection{Spacial Distribution of Economic Activities}

\section{Literature Review}

Geographically, most striking sign of economic activities are concentration and inequality among easy access region (such as coastal area) with cloistered region. Easy access region is easy to be reached with various transportation have its own advantage as commerce and trade area. Meanwhile cloistered region has advantage 
with abundance natural product. Regions with certain geographical characters earn certain economic activities concentration and become center of certain economy sector. Through this viewpoint, commerce and industrialization area represent a selective process that happened because its geographical position. For example, Surabaya has strategic coastal structure as big harbor which become center of trade area in East Java.

At some other area, concentration of manufacture industrial recognize located in particular area known as manufacturing belt area. Manufacturing belt area is cluster of producers from manufacture sector in a certain area for get positive externality. Similar spacial concentration is also found in industrial area in United Kingdom. Meanwhile, in most developing countries, trade and manufacture industry activities tend to concentrate around capital state such as Bangkok, New Delhi, Mexico City, Sao Paulo, and Jakarta, which marked a spacial system according to capital and manpower accumulation in urban agglomeration.

Traditional Location theories, such as Weber Theory (Henderson and Parsons, 1948), have notion that economic activity clustering emerge because of minimalization effect from transportation and production cost. Other theory approach is known as location interdependency based on duopoly theory. This theory try to explain that location represents producer's effort to expand their market area by maximize its selling and income. Common theory regarding company's location states that location factor can be classified into three group, which are demand, cost, and private consideration.

Classic clarification of economic activity spacially usually refers to two kinds of economic externality, which are localisation economies and urbanization economies. Both of it known as agglomeration economies which implies relation between urbanization and industrialization in development process. Localization Economies happened if company production cost decreases when total production increases. In other words, if some industrial companies located in the same area, they will enjoy some benefit called positive externalities. Localization efficiency related to companies concentration which have correspond activities each other have raised out industrial cluster/district phenomenon. Marshallian industrial district is Industrial cluster that basically represents production activity group which spacially concentrated and usually have specialization to one or two industry only. Urbanization economies happen if all production cost is decreasing while entire company's production in same location is increasing. Urbanization efficiency is because economics scale of entire companies are increasing. So urbanization efficiency gives benefit for all company in all town, not only certain company in industry.

\subsection{Region as Economic Unit}

Recently, spacial subunit from a country, region, becomes main player in economy and trade worldwide. Economics growth in China or India very depend into certain town/ region. Ohmae(2005) introduced concept of borderless nation and borderless region, stated that region is the real special unit with borderless character.Technology development give possibily to certain spacial unit to become center of economy activities. Technology advanced also support economic activities so it does not have to concentrate spacially in certain region. For example Batam's economomic activites orientation is leading to Singapore as its valuable market. Batam's orientation is not Jakarta as Indonesia's capital city. However, a region is more comprehend as an economic unit, not only administrative or political area. For archipelago country like Indonesia, complexity of politic and economic activities dominated national economy and it makes income disparities quite large because not entire Indonesians have the same possibility and ability to participate in economy activites. Region as economic unit become place to increase prosperity of all societies. In that region must be have enough economic players with good quality standar for government, worker, household with its strong purchasing power.

Ohmae (2005) identifies four aspects needed for region to become an economic unit that capable to involve in international economic dynamics to increase prosperity, such as:

1. The Region has to have enough market to attract foreign direct investment. Large market with high purchasing power represents strong demand potential which can support producers to provide service and goods

2. The Region have to open economy to worldwide. Openness means that the region is physically close to worldwide, supported by existence of transportation and distribution system to distribute effective and efficient.

3. The Region have to able to huddle up international world to motivate foreign investor and participate in global economic dynamics. Openness attitude has to show up in cultural and social life, and include in legislation system.

4. The Region has to become interesting place to conduct business. It is not only attach to valuable sustainable resource, but also becomes great place to work and maintain family. This last factor plays a great role in sustainable development of regional economics. 


\section{Methodology}

Quantitative analysis using Regional Product Mapping Model to analyse a nature of data regarding leading product matter by descriptive size of measurement which represent proxy of aggregate data. Some statistic descriptive measurement, such as average value of sampel, mean, modus, sample deviation standard, and sample data varians of trade indicators, are also employed.

\subsection{Mean of SLQ and TBI}

Aritmatics mean represents sum of all SLQ and TBI value divided by total sampel. Mean of SLQ formulated as follow

Mean of TBI formulation is

$$
\overline{X_{S L Q}}=\frac{\sum_{i=1}^{n} S L Q_{i}}{n}
$$

$$
\overline{X_{T B I}}=\frac{\sum_{i=1}^{n} T B I_{i}}{n}
$$

Where $\overline{X_{S L Q}}$ is mean of SLQ, $\overline{X_{T B I}}$ is mean of TBI, with $\mathrm{i}$ to represent certain product category, and $\mathrm{n}$ is sum of all product category. Mean of SLQ and TBI are counted in certain period of time. Increasing of SLQ mean shows comparative advantage of manufacture industry become more stronger. Meanwhile increasing of TBI mean

\begin{tabular}{|c|c|c|}
\hline $\begin{array}{l}\hat{\lambda} \\
\hat{\sigma} \\
\hat{\sigma}\end{array}$ & $\begin{array}{l}\text { Group B: } \\
\text { Net-importer } \\
\text { Strong Advantage } \\
(\text { SLQ }>0 \text { and TBI }<0)\end{array}$ & $\begin{array}{l}\text { Group A: } \\
\text { Net-exporter } \\
\text { Strong Advantage } \\
(\text { SLQ }>0 \text { and TBI }>0)\end{array}$ \\
\hline \multirow[t]{2}{*}{$\begin{array}{l}\stackrel{P}{v} \\
\stackrel{1}{u} \\
\text { v }\end{array}$} & $\begin{array}{l}\text { Group D: } \\
\text { Net-importer } \\
\text { Low Advantage } \\
(\text { SLQ }<0 \text { and TBI }<0)\end{array}$ & $\begin{array}{l}\text { Group C: } \\
\text { Net-exporter } \\
\text { Low Advantage } \\
(\text { SLQ }<0 \text { and TBI }>0)\end{array}$ \\
\hline & TBI $<0$ & $\begin{array}{l}\text { TBI < } 0 \\
\text { e Index (TBI) }\end{array}$ \\
\hline
\end{tabular}
shows export proportion of manufacture industry become bigger.

Figure 1. Regional Product Mapping Quadrant

Source: Model development by author

\subsection{Deviation Standart of $S L Q$ and TBI}

Deviation Standart is measurement of statistic value spreading. Deviation Standart measures how set value of data disseminate from average value. If value of data set spreads close to mean then Deviation Standart will near zero.Deviation standard measurement in analysis of international trade context dispersion value of SLQ and TBI. According to Balassa (in Widodo, 2010) deviation standard of comparative advantage value will express export product uniqueness at each state. Low level technology in developing country will export raw product with low value added and technological manufacture if it compared to export product from well-developed countries. Because developed countries yield high technological product.

\subsection{Skewness of SLQ dan TBI}

Skewness relates with distribution form of SLQ and TBI. A variable told to have symmetrical distribution if average value (mean), middle value (median) and mode, hence its distribution (skewness) will have symmetric form in both sides of center tinder. As its distribution become unsimmetrical if there are differences between average value, middle value and mode. Positive distribution of skewness by aritmatics when mode and median in highest position. On the contrary, negative distribution of skewness by aritmatics when mode and median in lowest position.

Positive skewness value of SLQ in certain years indicate that the country more intense at product with low comparative advantage. While positive skewness value of TBI indicates that the the state more focus at import product netto. Hence negative skewness value of SLQ indicate that the country more focus on high comparative product. While negative skewness value of TBI indicates that the the state more focus at export product netto. Analysis of skewness value annually shows specialization and shifting of SLQ and TBI. Balassa in 1977 (in Widodo, 2010) revealed about share of intensive product, structure of comparative advantage at each state, and also growth of manufacture export product specialization and diversification. Part of manufacture export product specialization and diversification growth express that developend countries tend to have wide 
production line of exporting product because its industrialization is already expand. High end technology are owned by developed countries will lead to have specialization at product from research and developing program.

\subsection{Regional Product Mapping Model}

Important indicators in Regional Product Mapping model to indentify and analyse leading export products a. Symmetric Location Quotient (SLQ)

SLQ index identify leading products and analyse strength of leading sector. The analysis can use data product, GDP and labour in leading sector. So analysis of SLQ index is not limited to identify leading product, but it can be broaden to analyse sectoral labour productivity and leading sector contribution to GDP.

\section{b. Trade Balance Index (TBI)}

TBI is used along with SLQ indicator forms regional product mapping which ranks export product to map product's strength and weakness and revealed potency product specialization.

\section{Result And Discussion}

Export commodities of East Java Province dominated by commodities from industrial sector, agricultural sector and mining sector.Data in table 1 used to calculate East Java TBI and some representing data for the calculation of East Java SLQ. All data for SLQ calculation also cover the Indonesia's import and export amount at same product. Because calculation of SLQ compares export strength of East Java with export strength of Indonesia.Palm oil product with HS code 151 has highest export value (Palm oil and its fractions; whether or not refined, but not chemically modified; Margarine; edible mixtures or preparations of animal or vegetable fats or oils or of fractions of different fats or oils of this chapter, other than edible fats or oils of heading no. 1516) equal to USD 1,469,213,815,000. The product has bigger export value than its import value. Export value export of palm oil product of sawit is true much bigger than other East Java export products because palm oil product in favourable in international market.

Coal products (Coal; briquettes, coal from manufactured fuels solid similar and ovoids) with HS code 270 is product with best export value USD 18,821,396,831,000. Its shown that export value larger than its import value.Export value is not best indicator in measuring import and export strength of a product because nett export only indicate differences among import and export value. Nett export has the following weakness

a. East Java's export strength product can not be compared to other product which is imported

b. Indonesia's export strength product can not be compared to other product which is imported

c. international trade balance weight unknown.

To overcome weakness of analysis use value export netto hence researcher use SLQ of TBI. Indicator as model Mapping of Product Area which can identify strength of leading export product in East Java and Indonesia. While TBI can measure international trade balance weight.Data at table 1 can be compared with data at table 2. It indicates that a type of product may represent leading product from East Java but not leading product nationally. Therefore, SLQ index is measurement to recognize leading product regionally (East Java) and nationally (Indonesia). Result of calculation using Regional Product Mapping model with TBI and SLQ indicators shall be as follows.

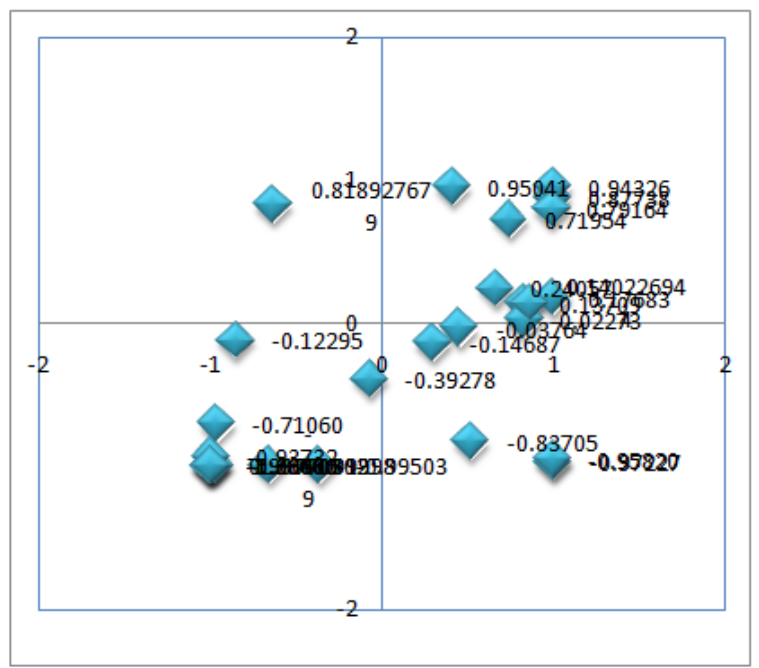

Figure 2. East Java Regional Product Mapping 2010

Source: data analyzing result 
Product with HS code 030 is prawn product. East Java fresh prawn export is one of leading export product. But in 2014, Oceaninc and Fishery Minister released the prohibition order to export fresh prawn from entire Indonesia so that all prawn product export value of East Java become zero. While in 2013, East Java still exported prawn product. Therefore, prawn product TBI calculation indicates -1 that means East Java consumer purely import prawn product.

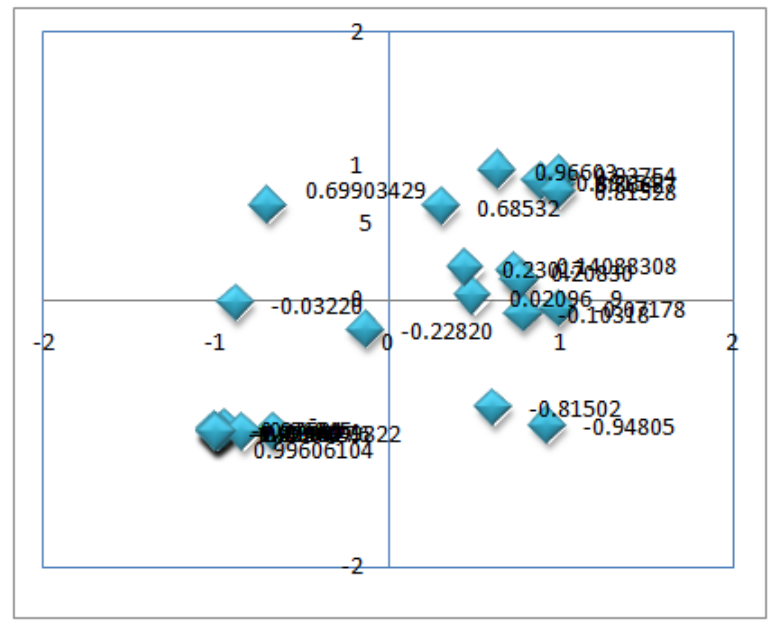

Figure 3. East Java Regional Product Mapping 2011

Source: data analyzing result

Export value netto of palm oil product from East Java is remarkable. But if we compare it with export value netto of palm oil product from Indonesia as a whole, export value netto of palm oil product from East Java is very low because palm oil product is leading export product in East Java but nor in Indonesia as a whole. It indicates that most of palm oil product is exported from East Java but other regions import palm oil from foreign countries.International trade product data from entire Indonesia required analysis using SLQ as export strength comparator of East Java product because an export product may become leading export product in a region but not a leading export product across regions in a nation. So, SLQ indicator recognize/mapping leading export product in a region and nation level.

Leading export products of East Java and Indonesia is in Grup A (first quadrant). While at Grup B (second quadrant) there are export products which only lead in regional/province scale, but not in national scale because East Java export proportion of the products is relatively small when it compared to export value of the same product type which yield in all provinces nationally. Briefly, process data analysis in Regional Product Mapping model in this research is comparing export and import value of export product from East Java (region) with export and import value of export product from Indonesia (National) at same 25 types of product. Result of Regional Product Mapping model indicates that 12 export product types in East Java included in Grup A (First Quadrant) with positive value of TBI and SLQ. The products represent leading export product regionally and nationally.

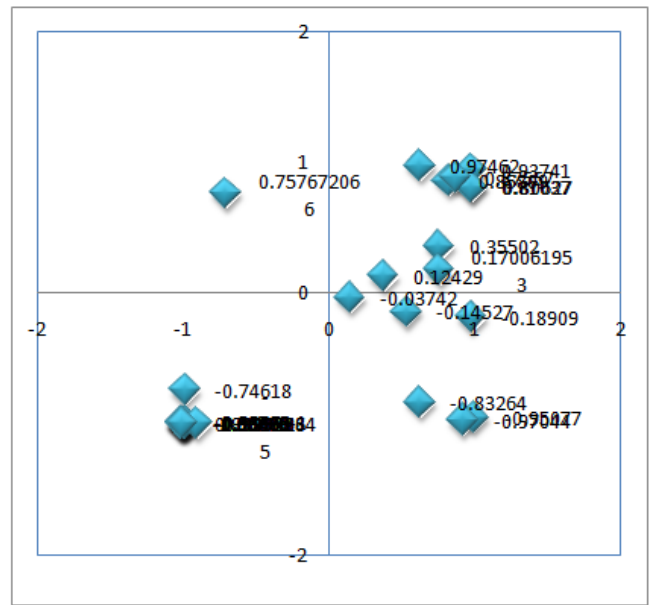

Figure 4. East Java Regional Product Mapping 2012

Source: data analyzing result 
At Grup B (Second Quadrant) only include 1 type of product with negative value of TBI and positive value of SLQ, that is cake raw material oil product. The product have regionally characteristic which have import proportion higher than its export proportion. But SLQ indicator shows that export strength of East Java products is higher than export strength of the same type of product which is exported from entire provinces in Indonesia.At Grup C (Third Quadrant) there are 6 export product types with positive TBI value positive and negative SLQ value. These products have characteristics regionally the products have higher export value than its import value. But SLQ indicates that export strength of East Java export products still low compared to export strength of the same export product type which is produced from entire provinces in Indonesia.Fourth quadrant is group products with negative value of TBI and SLQ. It means that these products represent product whit higher export value than its import. Strength of export products is weak in East Java and Indonesia.

Table 4. Descriptive Statistic Result

\begin{tabular}{|l|c|c|}
\hline Descritptive Statistics & TBI & SLQ \\
\hline Mean & 0.096189 & -0.249674 \\
\hline Median & 0.500000 & -0.440000 \\
\hline Maximum & 1.000000 & 1.000000 \\
\hline Minimum & -1.000000 & -1.000000 \\
\hline Std. Dev. & 0.867902 & 0.772707 \\
\hline Skewness & -0.291838 & 0.398881 \\
\hline Kurtosis & 1.253182 & 1.526225 \\
\hline
\end{tabular}

Source: data analyzing result

Standard deviation of TBI and SLQ show positive value if the export products are not owned specific characteristics yet because standard deviation measures data spread across average value. If data spread close to mean (average value) then standard deviation will near zero. Vice versa, if data spread away from mean (average value) then standard deviation will avoid zero. Average value of TBI and SLQ show improvement of export strength because it indicates that the increasing of SLQ average value represents reinforcement of East Java product advantage along time and improvement of TBI average value shows bigger proportion of East Java export product along time.Positive value of SLQ skewness in certain year indicates that the state more concentrate at product with low comparative advantage. While negative value of TBI skewness indicate that East Java more focus at nett export product. Producers in East Java have strong export potention although they must improve its exporting product advantage.

\section{References}

[1]. Agustin, Grisvia. 2014. The Product Mapping Analysis of Manufacturing Industry Products in Bilateral Trade between Indonesia and China in 1995-2011. International Journal of Economics and Research Volume 5 Issue 2. 25 April 2014

[2]. Statistical Center Institution. 2015. Statistic Official News. BPS East Java Office. No. 13/02/XIII. 5 Februari 2015.

[3]. 2015. East Java's Export Import Data 2015. BPS East Java Office.

[4]. 2015. Indonesia's Export Import Data. http://bps.go.id.

[5]. Balassa, B. (1965). Trade Liberalization and 'Revealed Comparative Advantage'. The Manchester School, 33: 99-123.

[6]. Dalum, Bent, Keld Laursen dan Gert Villumsen. 1998. Structural Change in OECD Export Specialisation Patterns: De-specialisation and 'Stickiness'. International Review of Applied Economics, Vol. 12, No. 3, 1998.

[7]. Damodar, Gujarati. 2003. Basic Econometrics, $4^{\text {th }}$ edition. New York: Mc Graw-Hill.

[8]. Indonesia's Trade and Industry Ministry. Indonesia's Trade and Industry Ministry Regulation 2011. http://regulasi.kemenperin.go.id/. Accessed at 8 August 2014.

[9]. Indonesia's Trade and Industry Ministry. Indonesia's Trade and Industry Ministry Regulation 2015. http://regulasi.kemenperin.go.id/site/peraturan/14/all. Accessed at 23 December 2015.

[10]. Koutsoyiannis, A. 1977. Theory of Econometrics: $2^{\text {nd }}$ Edition. Harper \& Row Publishers, Inc. Barnes \& Nobles Import Division, New York.

[11]. Krugman, Paul. R dan Maurice Obsfield. 2000. International Economics: Theory and Policy. Addison Wesley Longman. New York.

[12]. Laursen, K. 1998. Revealed Comparative Advantage and The Alternatives as Measures of International Specialisation. DRUID Working Paper No. 98-30. Danish Research Unit for Industrial Dynamics, Denmark.

[13]. Lee, Jim. 2011. Export Specialization and Economic Growth Around The World. Economic Systems 35 (2011) $45-63$.

[14]. Mah, Jai S. 2010. Export Promotion Policies, Export Composition and Economic Development of Korea. Law and Development Institute Inaugural Conference Sydney, Australia October 2010.

[15]. Muendler, Marc-Andreas. 2009. Converter from SITC to ISIC. University of California, San Diego, CESifo and NBER.8 Januari 2009.

[16]. Mundell, R.A. 1957. International Trade and Factor Mobility.American Economic Review 47(1957):321-35.

[17]. Nasution, Anwar. 2012. Optimalisation of Indonesia Trad Policy in ASEAN. Economic Institution Specialist Support for Economic Analysis Development in Indonesia (SEADI). Lecture Series Revision 2012, Trade Ministry, Jakarta 14 March 2012.

[18]. Orgun, Bilgin Orhan. 2012. Strategic Trade Policy Versus Free Trade. Procedia - Social and Behavioral Sciences 58 (2012) 1283 1292. $8^{\text {th }}$ International Strategic Management Conference.

[19]. Oskam, A.J., dkk. 2004. Trade Policies And Development of Less-Favoured Areas: Evidence From The Literature. Food Policy 29 (2004) 445-466.

[20]. Romer, David. 1996. Advanced Macroeconomics. New York: McGraw Hill.

[21]. Romer, Paul M. 1994.The Origins of Endogenous Growth.The Journal of Economic Perspectives, Vol. 8, No. 1. (Winter, 1994), pp. $3-22$. 
[22]. Salvatore, Dominick. 1997. International Economics.

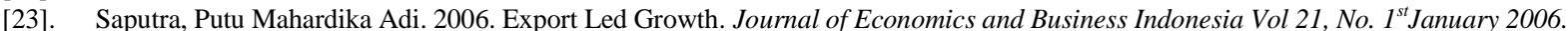

[24]. Sato, Sumie dan Mototsugu Fukushige. 2011. The North Korean Economy: Escape From Import-Led Growth. Journal of Asian Economics 22 (2011) 76-83.

[25]. Stubbs, Richard. 2002. ASEAN Plus Three: Emerging East Asian Regionalism?. Asian Survey, Vol. 42, No. 3 (May - Jun., 2002), halaman 440-455.

[26]. Todaro, Michael P. dan Stephen C. Smith. 2004. Economics Development in Third World.

[27]. UNCTAD. 2008. World Investment Report 2008. New York \& Geneva: UN

[28]. UNCTAD Statistics.http://unctadstat.unctad.org/.

[29]. Widodo, Tri. 2011. Comparative Advantage: Theory, Empirical Measures and Case Studies.

[30]. Yue, Changjun dan Ping Hua. 2002. Does Comparative Advantage Explains Patterns In China?. China Economics Review 13 (2002) 276-296.

[31]. http://www.mirrorservice.org/sites/home.edu/ntsbarsh/Business-stat/opre/partX.htm

Table 1. Export and Import Value of East Java 2014 (in thousand dollars)

\begin{tabular}{|c|c|c|c|c|}
\hline No. & HS Code & Information & Export & Import \\
\hline 1 & 030 & $\begin{array}{l}\text { Crustaceans; in shell or not, live, fresh, chilled, frozen, dried, } \\
\text { salted or in brine; smoked, cooked or not before or during } \\
\text { smoking; in shell, steamed or boiled, whether or not chilled }\end{array}$ & 0 & $5,876,103$ \\
\hline 2 & 090 & $\begin{array}{l}\text { Coffee, whether or not roasted or decaffeinated; husks and skins; } \\
\text { coffee substitutes containing coffee in any proportion }\end{array}$ & $171,179,885$ & $2,463,693$ \\
\hline 3 & 151 & $\begin{array}{l}\text { Palm oil and its fractions; whether or not refined, but not } \\
\text { chemically modified; Margarine; edible mixtures or preparations } \\
\text { of animal or vegetable fats or oils or of fractions of different fats } \\
\text { or oils of this chapter, other than edible fats or oils of heading no. } \\
1516\end{array}$ & $1,473,999,560$ & $4,785,745$ \\
\hline 4 & 180 & Cocoa; butter, fat and oil & $57,065,408$ & 210 \\
\hline 5 & 230 & $\begin{array}{l}\text { Oil-cake and other solid residues; whether or not ground or in the } \\
\text { form of pellets, resulting from the extraction of vegetable fats or } \\
\text { oils other than those of heading no. } 2304 \text { or } 2305 \text { from the } \\
\text { extraction of cotton seed oils pellets. }\end{array}$ & $33,817,073$ & $90,757,854$ \\
\hline 6 & 240 & $\begin{array}{l}\text { Cigars, cheroots, cigarillos and cigarettes; of tobacco or of } \\
\text { tobacco substitutes }\end{array}$ & $167,697,611$ & 334,194 \\
\hline 7 & 270 & $\begin{array}{l}\text { Coal; briquettes, ovoids and similar solid fuels manufactured } \\
\text { from coal }\end{array}$ & $392,790,777$ & $16,564,060$ \\
\hline 8 & 271 & $\begin{array}{l}\text { Petroleum gases and other gaseous hydrocarbons; Petroleum } \\
\text { coke, petroleum bitumen; other residues of petroleum oils or oils } \\
\text { obtained from bituminous minerals }\end{array}$ & $140,009,454$ & $15,415,200,264$ \\
\hline 9 & 382 & $\begin{array}{l}\text { Industrial monocarboxylic fatty acids; acid oils from refining; } \\
\text { industrial fatty alcohols; Prepared binders for foundry moulds or } \\
\text { cores; chemical products and preparations of the chemical or } \\
\text { allied industries (including those consisting of mixtures of natural } \\
\text { products), not elsewhere }\end{array}$ & $17,253,712$ & $227,023,522$ \\
\hline 10 & 400 & $\begin{array}{l}\text { Natural rubber, balata, gutta-percha, guayule, chicle and similar } \\
\text { gums; in primary forms or in plates, sheets or strip }\end{array}$ & $287,533,772$ & 997,827 \\
\hline 11 & 401 & New pneumatic tyres, of rubber & 326,943 & $19,854,461$ \\
\hline 12 & 440 & $\begin{array}{l}\text { Wood (including strips, friezes for parquet flooring, not } \\
\text { assembled), continuously shaped (tongued, grooved, v-jointed, } \\
\text { beaded or the like) along any edges, ends or faces, whether or not } \\
\text { planed, sanded or end-jointed }\end{array}$ & $397,365,600$ & 235,939 \\
\hline 13 & 441 & Plywood, veneered panels and similar laminated wood & $274,785,169$ & $33,773,498$ \\
\hline 14 & 480 & $\begin{array}{l}\text { Uncoated paper and paperboard, used for writing, printing or } \\
\text { other graphics, non perforated punch-cards and punch tape paper, } \\
\text { in rolls or rectangular sheets, of any size, other than paper }\end{array}$ & $365,605,893$ & $6,563,932$ \\
\hline 15 & 611 & $\begin{array}{l}\text { Jerseys, pullovers, cardigans, waistcoats and similar articles; } \\
\text { knitted or crocheted }\end{array}$ & 221,237 & 22,731 \\
\hline 16 & 640 & $\begin{array}{l}\text { Footwear; with outer soles of rubber, plastics, leather or } \\
\text { composition leather and uppers of textile materials }\end{array}$ & $294,469,829$ & 359,322 \\
\hline 17 & 710 & $\begin{array}{l}\text { Gold (including gold plated with platinum) unwrought or in } \\
\text { semi-manufactured forms, or in powder form }\end{array}$ & $240,070,580$ & 214 \\
\hline 18 & 711 & Miscellaneous manufactured articles, n.e.s. & $295,259,963$ & $11,001,601$ \\
\hline 19 & 740 & Copper; refined and copper alloys, unwrought & $755,806,646$ & $4,099,728$ \\
\hline 20 & 800 & Tin; unwrought & 14 & 69,397 \\
\hline 21 & 844 & $\begin{array}{l}\text { Printing machinery; used for printing by means of plates, } \\
\text { cylinders and other printing components of heading } 84.42 \text {; other } \\
\text { printers, copying machines and facsimile machines, whether or } \\
\text { not textile, leather, wallpaper, wrapping paper, linoleum or other } \\
\text { material }\end{array}$ & 443,818 & $2,100,444$ \\
\hline 22 & 852 & Video recording or reproducing apparatus & 486,935 & 91,529 \\
\hline 23 & 854 & $\begin{array}{l}\text { Insulated wire, cable and other electric conductors, connector } \\
\text { fitted or not; optical fibre cables of individually sheathed fibres, } \\
\text { whether or not assembled with electric conductors or fitted with }\end{array}$ & $254,364,310$ & $9,924,136$ \\
\hline
\end{tabular}




\begin{tabular}{|l|l|l|l|l|}
\hline 24 & 870 & $\begin{array}{l}\text { Motor cars and other motor vehicles; principally designed for the } \\
\text { transport of persons (other than those of heading no. 8702), } \\
\text { including station wagons and racing cars; Motor vehicles; parts } \\
\text { and accessories, of heading no. 8701 to 8705 }\end{array}$ & $16,951,297$ \\
\hline 25 & 940 & Furniture and parts thereof, n.e.c. in chapter 94 & $295,259,963$ & $11,001,601$ \\
\hline
\end{tabular}

Source: Statistical Center Instituition, 2015.

Table 2. Export and Import Value of Indonesia 2014 (in thousand dollars)

\begin{tabular}{|c|c|c|c|c|}
\hline No. & Kode HS & Information & Export & Import \\
\hline 1 & 030 & $\begin{array}{l}\text { Crustaceans; in shell or not, live, fresh, chilled, frozen, dried, salted } \\
\text { or in brine; smoked, cooked or not before or during smoking; in shell, } \\
\text { steamed or boiled, whether or not chilled. }\end{array}$ & $1,894,729.276$ & $84,685.787$ \\
\hline 2 & 090 & $\begin{array}{l}\text { Coffee, whether or not roasted or decaffeinated; husks and skins; } \\
\text { coffee substitutes containing coffee in any proportion }\end{array}$ & $1,532,354.332$ & $181,078.969$ \\
\hline 3 & 151 & $\begin{array}{l}\text { Palm oil and its fractions; whether or not refined, but not chemically } \\
\text { modified; Margarine; edible mixtures or preparations of animal or } \\
\text { vegetable fats or oils or of fractions of different fats or oils of this } \\
\text { chapter, other than edible fats or oils of heading no. } 1516\end{array}$ & $810,509.173$ & $41,689.104$ \\
\hline 4 & 180 & Cocoa; butter, fat and oil & $1,418,746.827$ & $290,862.760$ \\
\hline 5 & 230 & $\begin{array}{l}\text { Oil-cake and other solid residues; whether or not ground or in the } \\
\text { form of pellets, resulting from the extraction of vegetable fats or oils } \\
\text { other than those of heading no. } 2304 \text { or } 2305 \text { from the extraction of } \\
\text { cotton seed oils pellets. }\end{array}$ & $52,265.439$ & $1,291,811.994$ \\
\hline 6 & 240 & $\begin{array}{l}\text { Cigars, cheroots, cigarillos and cigarettes; of tobacco or of tobacco } \\
\text { substitutes }\end{array}$ & $194,006.581$ & $805,565.048$ \\
\hline 7 & 270 & $\begin{array}{l}\text { Coal; briquettes, ovoids and similar solid fuels manufactured from } \\
\text { coal }\end{array}$ & $18,862,535.603$ & $41,138.772$ \\
\hline 8 & 271 & $\begin{array}{l}\text { Petroleum gases and other gaseous hydrocarbons; Petroleum coke, } \\
\text { petroleum bitumen; other residues of petroleum oils or oils obtained } \\
\text { from bituminous minerals }\end{array}$ & $14,750,231.954$ & $38,262,163.090$ \\
\hline 9 & 382 & $\begin{array}{l}\text { Industrial monocarboxylic fatty acids; acid oils from refining; } \\
\text { industrial fatty alcohols; Prepared binders for foundry moulds or } \\
\text { cores; chemical products and preparations of the chemical or allied } \\
\text { industries (including those consisting of mixtures of natural } \\
\text { products), not elsewhere }\end{array}$ & $485,149.687$ & $760,536.403$ \\
\hline 10 & 400 & $\begin{array}{l}\text { Natural rubber, balata, gutta-percha, guayule, chicle and similar } \\
\text { gums; in primary forms or in plates, sheets or strip }\end{array}$ & $249,316.092$ & $290,263.137$ \\
\hline 11 & 401 & New pneumatic tyres, of rubber & $1,705,594.595$ & $641,786.931$ \\
\hline 12 & 440 & $\begin{array}{l}\text { Wood (including strips, friezes for parquet flooring, not assembled), } \\
\text { continuously shaped (tongued, grooved, v-jointed, beaded or the like) } \\
\text { along any edges, ends or faces, whether or not planed, sanded or } \\
\text { end-jointed }\end{array}$ & $559,853.127$ & $40,655.348$ \\
\hline 13 & 441 & Plywood, veneered panels and similar laminated wood & $1,820,872.290$ & $228,953.342$ \\
\hline 14 & 480 & $\begin{array}{l}\text { Uncoated paper and paperboard, used for writing, printing or other } \\
\text { graphics, non perforated punch-cards and punch tape paper, in rolls } \\
\text { or rectangular sheets, of any size, other than paper }\end{array}$ & $579,169.299$ & $451,869.543$ \\
\hline 15 & 611 & $\begin{array}{l}\text { Jerseys, pullovers, cardigans, waistcoats and similar articles; knitted } \\
\text { or crocheted }\end{array}$ & $1,471,613.882$ & $2,694,496.676$ \\
\hline 16 & 640 & $\begin{array}{l}\text { Footwear; with outer soles of rubber, plastics, leather or composition } \\
\text { leather and uppers of textile materials }\end{array}$ & $3,722,624.409$ & $545,799.892$ \\
\hline 17 & 710 & $\begin{array}{l}\text { Gold (including gold plated with platinum) unwrought or in } \\
\text { semi-manufactured forms, or in powder form }\end{array}$ & $1,807,287.512$ & $154,651.920$ \\
\hline 18 & 711 & Miscellaneous manufactured articles, n.e.s. & $586,661.130$ & $1,981,743.943$ \\
\hline 19 & 740 & Copper; refined and copper alloys, unwrought & $1,928,723.313$ & $978,394.573$ \\
\hline 20 & 800 & Tin; unwrought & $2,062,329.092$ & $16,315.441$ \\
\hline 21 & 844 & $\begin{array}{l}\text { Printing machinery; used for printing by means of plates, cylinders } \\
\text { and other printing components of heading } 84.42 \text {; other printers, } \\
\text { copying machines and facsimile machines, whether or not textile, } \\
\text { leather, wallpaper, wrapping paper, linoleum or other material }\end{array}$ & $111,782.009$ & $475,811.679$ \\
\hline 22 & 852 & Video recording or reproducing apparatus & $1,115,857.413$ & $274,904.840$ \\
\hline 23 & 854 & $\begin{array}{l}\text { Insulated wire, cable and other electric conductors, connector fitted } \\
\text { or not; optical fibre cables of individually sheathed fibres, whether or } \\
\text { not assembled with electric conductors or fitted }\end{array}$ & $40,928.097$ & $226,485.877$ \\
\hline 24 & 870 & $\begin{array}{l}\text { Motor cars and other motor vehicles; principally designed for the } \\
\text { transport of persons (other than those of heading no. 8702), including } \\
\text { station wagons and racing cars; Motor vehicles; parts and } \\
\text { accessories, of heading no. } 8701 \text { to } 8705\end{array}$ & $4,970,082.546$ & $10,734,786.866$ \\
\hline 25 & 940 & Furniture and parts thereof, n.e.c. in chapter 94 & $1,813,948.609$ & $605,321.273$ \\
\hline
\end{tabular}

Source: Statistical Center Instituition, 2015.

Table 3. TBI and SLQ indicators in East Java 2014

\begin{tabular}{|l|l|l|l|l|}
\hline No. & Kode HS & Keterangan Produk & TBI & SLQ \\
\hline
\end{tabular}




\begin{tabular}{|c|c|c|c|c|}
\hline 1 & 030 & $\begin{array}{l}\text { Crustaceans; in shell or not, live, fresh, chilled, frozen, dried, salted or in brine; } \\
\text { smoked, cooked or not before or during smoking; in shell, steamed or boiled, } \\
\text { whether or not chilled. }\end{array}$ & -1.00000 & -1.00000 \\
\hline 2 & 090 & $\begin{array}{l}\text { Coffee, whether or not roasted or decaffeinated; husks and skins; coffee } \\
\text { substitutes containing coffee in any proportion }\end{array}$ & 0.97162 & -0.01282 \\
\hline 3 & 151 & $\begin{array}{l}\text { Palm oil and its fractions; whether or not refined, but not chemically modified; } \\
\text { Margarine; edible mixtures or preparations of animal or vegetable fats or oils or } \\
\text { of fractions of different fats or oils of this chapter, other than edible fats or oils of } \\
\text { heading no. } 1516\end{array}$ & 0.99353 & 0.88143 \\
\hline 4 & 180 & Cocoa; butter, fat and oil & 0.99999 & -0.48045 \\
\hline 5 & 230 & $\begin{array}{l}\text { Oil-cake and other solid residues; whether or not ground or in the form of pellets, } \\
\text { resulting from the extraction of vegetable fats or oils other than those of heading } \\
\text { no. } 2304 \text { or } 2305 \text { from the extraction of cotton seed oils pellets. }\end{array}$ & -0.45708 & 0.69904 \\
\hline 6 & 240 & Cigars, cheroots, cigarillos and cigarettes; of tobacco or of tobacco substitutes & 0.99602 & 0.76586 \\
\hline 7 & 270 & Coal; briquettes, ovoids and similar solid fuels manufactured from coal & 0.91907 & -0.69249 \\
\hline 8 & 271 & $\begin{array}{l}\text { Petroleum gases and other gaseous hydrocarbons; Petroleum coke, petroleum } \\
\text { bitumen; other residues of petroleum oils or oils obtained from bituminous } \\
\text { minerals }\end{array}$ & -0.98200 & -0.84703 \\
\hline 9 & 382 & $\begin{array}{l}\text { Industrial monocarboxylic fatty acids; acid oils from refining; industrial fatty } \\
\text { alcohols; Prepared binders for foundry moulds or cores; chemical products and } \\
\text { preparations of the chemical or allied industries (including those consisting of } \\
\text { mixtures of natural products), not elsewhere }\end{array}$ & 0.85874 & 0.60652 \\
\hline 10 & 400 & $\begin{array}{l}\text { Natural rubber, balata, gutta-percha, guayule, chicle and similar gums; in primary } \\
\text { forms or in plates, sheets or strip }\end{array}$ & 0.99308 & 0.81921 \\
\hline 11 & 401 & New pneumatic tyres, of rubber & -0.96760 & -0.99666 \\
\hline 12 & 440 & $\begin{array}{l}\text { Wood (including strips, friezes for parquet flooring, not assembled), } \\
\text { continuously shaped (tongued, grooved, v-jointed, beaded or the like) along any } \\
\text { edges, ends or faces, whether or not planed, sanded or end-jointed }\end{array}$ & 0.99881 & 0.72194 \\
\hline 13 & 441 & Plywood, veneered panels and similar laminated wood & 0.78109 & 0.13670 \\
\hline 14 & 480 & $\begin{array}{l}\text { Uncoated paper and paperboard, used for writing, printing or other graphics, non } \\
\text { perforated punch-cards and punch tape paper, in rolls or rectangular sheets, of } \\
\text { any size, other than paper }\end{array}$ & 0.96473 & 0.69268 \\
\hline 15 & 611 & Jerseys, pullovers, cardigans, waistcoats and similar articles; knitted or crocheted & 0.81366 & -0.99738 \\
\hline 16 & 640 & $\begin{array}{l}\text { Footwear; with outer soles of rubber, plastics, leather or composition leather and } \\
\text { uppers of textile materials }\end{array}$ & 0.99756 & -0.18331 \\
\hline 17 & 710 & $\begin{array}{l}\text { Gold (including gold plated with platinum) unwrought or in semi-manufactured } \\
\text { forms, or in powder form }\end{array}$ & 1.00000 & 0.07364 \\
\hline 18 & 711 & Miscellaneous manufactured articles, n.e.s. & 0.98921 & 0.54742 \\
\hline 19 & 740 & Copper; refined and copper alloys, unwrought & -0.99960 & -1.00000 \\
\hline 20 & 800 & Tin; unwrought & -0.65112 & -0.93304 \\
\hline 21 & 844 & $\begin{array}{l}\text { Printing machinery; used for printing by means of plates, cylinders and other } \\
\text { printing components of heading } 84.42 \text {; other printers, copying machines and } \\
\text { facsimile machines, whether or not textile, leather, wallpaper, wrapping paper, } \\
\text { linoleum or other material }\end{array}$ & 0.68354 & -0.99241 \\
\hline 22 & 852 & $\begin{array}{l}\text { Telephone sets, including telephones for cellular networks or for other wireless } \\
\text { networks; other apparatus for the transmission or reception of voice, images or } \\
\text { other data (including wired/wireless); Video recording or reproducing apparatus }\end{array}$ & 0.92490 & 0.96378 \\
\hline 23 & 854 & $\begin{array}{l}\text { Insulated wire, cable and other electric conductors, connector fitted or not; } \\
\text { optical fibre cables of individually sheathed fibres, whether or not assembled } \\
\text { with electric conductors or fitted }\end{array}$ & -0.70312 & -0.98968 \\
\hline 24 & 870 & $\begin{array}{l}\text { Motor cars and other motor vehicles; principally designed for the transport of } \\
\text { persons (other than those of heading no. 8702), including station wagons and } \\
\text { racing cars; Motor vehicles; parts and accessories, of heading no. } 8701 \text { to } 8705\end{array}$ & 0.92816 & 0.17362 \\
\hline 25 & 940 & Furniture and parts thereof, n.e.c. in chapter 94 & 1.00000 & 0.94843 \\
\hline
\end{tabular}

Source: data calculation result

Grisvia Agustin. Born in Indonesia at 18 August 1980. Accomplish Doctoral Degree Program at 2014. Now become lecturer since 2015. Chief of Tax Center Ecnomics Faculty (2015-now). Editorial Board of Economics and Study Development Journal (2015-now). 